\title{
Effects of alternative deep bedding options on dairy cow preference, lying behavior, cleanliness, and teat end contamination
}

\author{
T. Wolfe, ${ }^{*}$ E. Vasseur, ${ }^{*}$ T. J. DeVries, $\dagger$ and R. Bergeron ${ }^{1}$ \\ *Department of Animal Science, McGill University, Ste-Anne-de-Bellevue, QC, H9X 3V9, Canada \\ †Department of Animal Biosciences, University of Guelph, Guelph, ON, N1G 2W1, Canada
}

\begin{abstract}
Cows spend more time lying down when stalls are soft and dry, and bedding plays a key role in the comfort of the lying surface. The first objective of this study (experiment 1) was to compare cow preference for 2 types of alternative deep-bedding materials, switchgrass and switchgrass-lime, using wheat straw on a rubber mat as a control. Nine Holstein lactating cows were submitted in trios to a 3 -choice preference test over $14 \mathrm{~d}$ (2 $\mathrm{d}$ of adaptation, $3 \mathrm{~d}$ of restriction to each stall, and $3 \mathrm{~d}$ of free access to all 3 stalls). Cows were housed individually in pens containing 3 stalls with different lying surfaces: (1) rubber mat with chopped wheat straw (WS); (2) deep-bedded switchgrass (SG); and (3) deep-bedded switchgrass, water, and lime mixture (SGL). The second objective (experiment 2) was to test, in freestall housing, the effects of these 3 types of bedding on lying behavior, cow cleanliness, and teat end bacterial contamination. Bedding treatments were compared in a $3 \times 3$ Latin square design using 24 cows split into groups of 8 , with bedding materials being switched every 4 wk. Lying behavior was measured with data loggers in both studies. During experiment 1 , cows chose to spend more time lying and had more frequent lying bouts on $\mathrm{SG}(9.4 \mathrm{~h} / \mathrm{d} ; 8.2$ bouts/d) than on SGL $(1.0 \mathrm{~h} / \mathrm{d} ; 0.9$ bouts/d). They also spent more time standing and stood more frequently in stalls with SG $(2.0 \mathrm{~h} / \mathrm{d} ; 10.1$ bouts/d) than in those with SGL $(0.6 \mathrm{~h} / \mathrm{d} ; 2.6$ bouts/d), and stood longer in stalls with SG than with WS $(0.6 \mathrm{~h} / \mathrm{d})$. In experiment 2 , the total lying time, frequency of lying bouts, and mean lying bout duration were, on average, $9.7 \pm 1.03 \mathrm{~h} / \mathrm{d}, 8.2$ $\pm 0.93 \mathrm{bouts} / \mathrm{d}$, and $1.2 \pm 0.06 \mathrm{~h} /$ bout, respectively, and did not differ between treatments. No treatment effects were found for cow cleanliness scores. Bedding dry matter was highest for SG (74.1\%), lowest for SGL
\end{abstract}

Received November 25, 2016.

Accepted September 11, 2017.

${ }^{1}$ Corresponding author: rbergero@uoguelph.ca
$(63.5 \%)$, and intermediate for WS $(68.6 \%)$ [standard error of the mean $(\mathrm{SEM})=1.57 \%]$. This may explain the higher teat end count of coliforms for cows on SGL $\left(0.92 \log _{10} \mathrm{cfu} / \mathrm{g}\right)$ compared with WS (0.13 $\log _{10}$ $\mathrm{cfu} / \mathrm{g})\left(\mathrm{SEM}=0.144 \log _{10} \mathrm{cfu} / \mathrm{g}\right)$. In conclusion, cows preferred the deep-bedded switchgrass surface over the other 2 surfaces, and deep-bedded switchgrass appears to be a suitable bedding alternative for dairy cows.

Key words: dairy cow, deep bedding, preference, switchgrass

\section{INTRODUCTION}

Bedding plays a key role in the comfort of the lying surface (Tucker et al., 2009). When offered the choice, cows have been observed to lie down more often on concrete covered with a large amount of straw than on lightly bedded soft rubber mats (Manninen et al., 2002), and spend more time lying in deep-bedded sawdust and deep-bedded sand stalls than in stalls with mattresses covered with 2 to $3 \mathrm{~cm}$ of sawdust (Tucker et al., 2003). Furthermore, larger amounts of sawdust bedding positively affected lying preferences of cows on geotextile mattress (Tucker and Weary, 2004). For each additional kilogram of sawdust or straw on a mattress, cows increased their daily lying time by $12 \mathrm{~min}$ (Tucker and Weary, 2004; Tucker et al., 2009).

In addition to being preferred by cows, deep-bedded stalls, either with sawdust or straw, have been associated with a lower incidence of and less severe hock lesions (Weary and Taszkun, 2000). Similarly, hock lesions are reported to be less frequent in cows housed on deep-bedded sand compared with cows on mattresses (Fulwider et al., 2007), and the severity of injured hocks was reported to be lower on farms using deep litter material, such as compost, sand, and horse manure, compared with farms using foam mattresses (van Gastelen et al., 2011). In a recent survey of 76 farms, the risk of hock injuries decreased with bedding at least 10 cm deep or with sand bedding (Barrientos et al., 2013).

The type of lying surface may also play an important role in cows' mammary health, by affecting cow 
cleanliness and exposure to environmental bacteria. For instance, cows had better leg and udder hygiene scores on mattresses or waterbeds than on sand (Fulwider et al., 2007), and cows on sawdust had cleaner udders than those on sand (Zdanowicz et al., 2004). More recently, however, no differences in cleanliness scores were found between cows housed on mattresses and various deep bedding materials, including sand (van Gastelen et al., 2011), or between deep-bedded strawlime and Miscanthus (silvergrass)-lime (van Weyenberg et al., 2015). Bedding types also vary in their ability to support bacterial growth, with sand typically having a lower bacterial count than organic beddings (Fairchild et al., 1982; van Gastelen et al., 2011). Farms using organic bedding commonly add lime in an attempt to reduce bacterial growth (Hogan et al., 1999). Hydrated lime added to bedding has been shown to elevate $\mathrm{pH}$ and lower the moisture content, reducing exposure of teats to environmental mastitis pathogens for $1 \mathrm{~d}$ with sawdust (Hogan and Smith, 1997) and recycled manure (Hogan et al., 1999). Kristula et al. (2008) tested several bedding treatments to reduce mastitis bacterial growth and found that lime was the only treatment that significantly reduced bacterial counts.

Even though farmers are aware of the importance of bedding, the cost associated with good-quality bedding encourages them to either use less bedding or look for alternatives (van Weyenberg et al., 2015). Switchgrass (Panicum virgatum L.), a high-yielding, long-term perennial grass growing on marginal land (Sanderson et al., 2006), could constitute a promising bedding alternative. It is well adapted for growth under a temperate climate, is disease and pest resistant, requires low fertilizer applications, and is relatively inexpensive to grow and harvest (Frigon et al., 2012). To our knowledge, the use of switchgrass as an alternative source of bedding, either alone or in combination with lime, has not been extensively investigated in controlled studies. The first objective of this study (experiment 1) was to compare cow preference for 2 types of deep bedding materials: switchgrass and switchgrass-lime "mattress," using straw on a rubber mat as a control. The second objective (experiment 2) was to assess the effect of these deep bedding types on lying behavior, cow cleanliness, and teat end bacterial contamination.

\section{MATERIALS AND METHODS}

Two experiments were conducted at the University of Guelph's Alfred Campus Organic Dairy Research Farm (Alfred, ON, Canada). Animals were cared for according to the standards and guidelines of the Canadian Council on Animal Care (CCAC, 2009) and approved by the University of Guelph Animal Care Committee.

\section{Experiment 1}

Animals, Housing, and Bedding Types. Six primiparous and 3 multiparous (4 to 5 lactations) early- to late-lactation Holstein cows (mean $\pm \mathrm{SD}$, BW: 683.3 $\pm 100.93 \mathrm{~kg}$; DIM: 13 to $436 \mathrm{~d})$ were used. Before the experiment, all cows were housed in a freestall facility, on stalls bedded with sawdust over mattresses, and throughout the experiment, each cow was housed individually in a test pen consisting of 3 side-by-side wall-facing freestalls with a feed alley. Cows had been previously exposed to these pens as heifers, during the weeks before first breeding. Three similar test pens $(5.03 \times 3.66 \mathrm{~m})$ were used. Stalls in each pen were 1.14 $\mathrm{m}$ wide and $3.05 \mathrm{~m}$ long with a bed length of $2.53 \mathrm{~m}$. The neck rail height was $1.27 \mathrm{~m}$ from the stall surface and no brisket board was installed. Flexible stall dividers were installed (GreenFreestall, Tags4All Global Inc., Mitchell, ON, Canada). A box made of recycled plastic lumber $(252.5 \times 118 \times 14 \mathrm{~cm})$ was built for each stall to accommodate the deep-bedded lying surfaces. Curb height for each stall was $14 \mathrm{~cm}$. Each stall in the test pens was bedded with a different material (bedding type): (1) rubber mat (Animat rubber mats $1.9 \mathrm{~cm}$ thickness; Animat Inc., Saint-Élie d'Orford, QC, Canada) covered with 2 to $3 \mathrm{~cm}$ of chopped wheat straw (WS); (2) deep-bedded switchgrass (SG), consisting of approximately $14 \mathrm{~cm}$ of compacted chopped switchgrass; and (3) deep-bedded switchgrass and lime (SGL), consisting of approximately $14 \mathrm{~cm}$ of a compacted base mixture of switchgrass, water, and lime $\left(\mathrm{CaCO}_{3}, \mathrm{pH} 8.0\right.$ to 9.2 ; Graymont, Salt Lake City, UT) in a 1:3:6 ratio based on weight, covered with 2 to 3 $\mathrm{cm}$ of top mixture in a ratio of 1:1:1. The floor under the rubber mat stalls was raised to ensure that the edges of the box did not extend above the bedded lying surface. Bedding types (WS, SG, and SGL) were semi-randomly allocated to the stall locations (left, middle, and right) and balanced across stall locations. Both straw and switchgrass bales were chopped using a TMR mixer (model 400 pull type; Supreme International Ltd., Wetaskiwin, AB, Canada) to a length of approximately 2 to $4 \mathrm{~cm}$ and 5 to $10 \mathrm{~cm}$, respectively. Feces were removed and bedding was leveled to curb twice daily during morning and afternoon milkings, which started at 0530 and $1930 \mathrm{~h}$, respectively. Fresh bedding material was added (WS: $2 \mathrm{~kg}$; SG: $2 \mathrm{~kg}$; SGL: $2.4 \mathrm{~kg}$ ) to each stall every morning.

Preference Tests. Trios of animals ( $\mathrm{n}=9$ total) were tested simultaneously, one in each test pen for 14-d periods ( $2 \mathrm{~d}$ of adaptation, $9 \mathrm{~d}$ of restriction, and $3 \mathrm{~d}$ of free choice). During the adaptation phase, cows had access to all 3 stalls. During the restriction phase, cows were sequentially provided access to only one of 
the stall types for a period of $3 \mathrm{~d}$ without replacement. Order of access to the 3 stalls was randomly assigned, and access to a single stall was achieved by blocking the other stalls with nylon rope tied to the stall separators. During the free-choice phase, all cows had equal access to the 3 bedding types. Cows had free access to water, feed, and alley space at all times.

Cows were video recorded during the free-choice phase (3 d). Two cameras (WV-BP124 CCTV, Panasonic, Osaka, Japan) attached to a digital video recorder (ADT A-XDP16E-3TB, ADT Security Services Inc., Mississauga, ON, Canada) were used for recording (a single camera for pen 1 and 2 and a single camera for pen 3 ). Video recordings were watched continuously and the following behaviors were noted: time spent lying and standing in the stalls, number of lying and standing events, as per Tucker et al. (2003). Lying behaviors were also recorded continuously using electronic data loggers (Hobo Pendant G Acceleration Data Logger, Onset Computer Corp., Bourne, MA), following Ledgerwood et al. (2010). On d 1 of each free-choice phase, data loggers were wrapped in veterinary bandaging (Vetrap; CoFolex, Andover Coated Products Inc., Salisbury, MA) and attached to a hind leg of each cow using veterinary bandaging. Loggers were programmed to record the position of the cow (lying or standing) at 1 min-intervals and removed on d 3 of each free-choice phase during the morning milking. Data were downloaded and daily duration of lying and standing, bout frequency, and mean bout duration were computed using Excel macros (Microsoft Corp., Redmond, WA) for each 3-d period.

Statistical Analyses. Data were expressed as daily averages for each cow by bedding type and phase. Dependent variables (daily duration of lying and standing, bout frequency, and mean bout duration) were tested for normality using the Shapiro-Wilk test (PROC UNIVARIATE) of SAS (version 9.4; SAS Institute Inc., Cary, NC). All variables had non-normal distributions and, therefore, nonparametric analyses were used. Friedman's rank test (PROC FREQ) was used to examine the difference among bedding types in daily duration of lying and standing, bout frequency, and mean bout duration. For significant variables, post hoc Wilcoxon signed rank tests (PROC UNIVARIATE) with a Bonferroni adjustment were used to make pairwise comparisons between bedding types.

\section{Experiment 2}

Animals, Housing, and Treatments. Twentyfour lactating Holstein cows in early to late lactation (parity range from 1 to 5 , with 9 cows in parity 1; DIM range from 23 to $323 \mathrm{~d}$; BW: $704.4 \pm 54.17 \mathrm{~kg}$ ) with no history of mastitis were used in a $3 \times 3$ Latin square design with $28-\mathrm{d}$ periods ( $7 \mathrm{~d}$ of bedding adaptation and $21 \mathrm{~d}$ of data collection). Cows were divided into 3 groups of 8 , balanced for BW and DIM, and groups were randomly assigned to a treatment $(\mathrm{n}=3)$. Cows had free access to water and feed and were housed in freestalls with 13 stalls facing a wall and 11 stalls facing the feeding alley (width of $1.3 \mathrm{~m}$, length of $2.1 \mathrm{~m}$, and bed length of $1.9 \mathrm{~m}$ ). The neck rail and brisket board heights were 1.2 and $0.15 \mathrm{~m}$, respectively.

The barn was divided into 3 experimental sections and the same bedding treatments as in experiment 1 (WS, SG, and SWL) were randomly allocated to the stalls in the experimental sections (8 stalls/section; cow: stall ratio of 1:1). Treatments and groups of cows were rotated through each of the 3 experimental sections of the barn over the course of the study. Feces were removed and bedding was leveled to the curb twice daily during morning and afternoon milkings. Fresh bedding material was added (WS: $2 \mathrm{~kg}$; SG: $3 \mathrm{~kg}$; SGL: $2.4 \mathrm{~kg}$ ) to each stall every morning. Morning and afternoon milkings started at 0530 and $1930 \mathrm{~h}$, respectively, and lasted approximately $3.5 \mathrm{~h}$ each. Experimental groups of cows were separately brought to the milking parlor, and after milking, waited in the feeding area until all cows had been milked. Cows were sent on pasture for up to $0.5 \mathrm{~h}$ per day, between the morning and afternoon milkings.

Bedding DM and Cow Cleanliness. On d 13, 20 , and 27 of each period, composite bedding samples were collected from 5 locations on the back one-third of each stall in a garbage bag. Approximately $2 \mathrm{~kg}$ of bedding was collected from each stall. Dry matter content of top bedding materials was then analyzed following standard procedures (AOAC International, 2006). Leg, flank, and udder cleanliness were scored on a scale of 0 to 3 (with 0 being lightly and 3 being very heavily contaminated with manure). The standard operating procedures used were those available on the Canadian Dairy Research Portal (https://www.dairyresearch.ca/ cow-comfort.php\#self; Vasseur et al., 2015).

Teat End Bacterial Contamination. Teat swabs were taken from each teat of each cow on d 13 and 27 of each period and collected before the morning milking using sterile and medium-free BBL Culture Swabs (BD Microbiology Systems, Canada), as per Zdanowicz et al. (2004). Teat swabs were kept on ice and subsequently pooled by cow across the 4 teats and placed in a single 15 -mL Falcon tube containing $2 \mathrm{~mL}$ of peptone solution. All tubes were placed and secured in a rack and sent in a Styrofoam cooler with ice packs to Animal Health Laboratory (Guelph, ON, Canada) for analysis of coliforms, Klebsiella spp., and Streptococcus spp. For those analyses, a neat (undiluted) sample, a 1:10 dilution, and 
Table 1. Lying and standing daily duration, bout frequency, and bout duration for the 3 bedding types in experiment 1

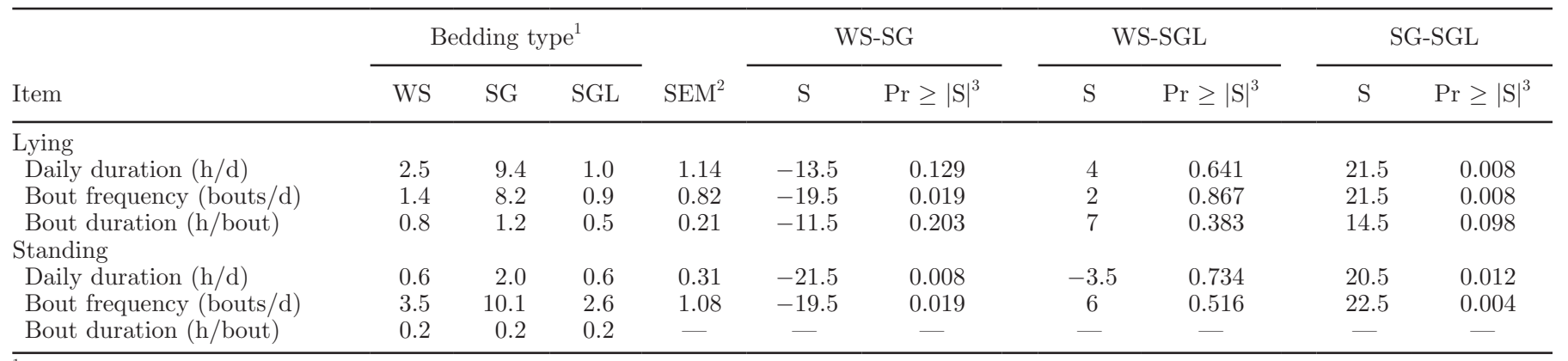

${ }^{1} \mathrm{WS}=$ straw; $\mathrm{SG}=$ switchgrass; $\mathrm{SGL}=$ switchgrass, water, lime mixture.

${ }^{2}$ Pooled SEM.

${ }^{3}$ Post hoc Wilcoxon signed rank tests with a Bonferroni adjustment were used for pairwise comparisons $(P<0.017)$. S is the signed rank statistic.

a 1:100 dilution of the samples were plated on 3 types of selective agars. For coliforms, MacConkey agar plates were inoculated and incubated at $37^{\circ} \mathrm{C}$ for $24 \pm 2 \mathrm{~h}$. The streptococci selective agar consisted of Columbia blood agar base with the addition of streptococci selective supplement (colistin sulfate and oxolinic acid). The Klebsiella spp. selective agar consisted of a MacConkey agar base with the addition of inositol and carbenicillin (Bagley and Seidler, 1978). The streptococci and Klebsiella spp. selective plates were incubated at $35^{\circ} \mathrm{C}$ for $24 \pm 2$ h. Bacterial colonies were identified based on their shape, size, color, and texture, and counts were expressed as colony-forming units per gram.

Lying Behavior. Lying behavior was recorded continuously from d 7 , using the same equipment and recording interval as in experiment 1 . Loggers were switched every $7 \mathrm{~d}$ during the morning milking. Data were downloaded and daily duration of lying, bout frequency, and mean bout duration were computed using Excel macros (Microsoft Corp.) for each week of data collection.

Statistical Analysis. Data were summarized by group and week within treatment period. Variables were tested for normality using PROC UNIVARIATE of SAS (version 9.4; SAS Institute Inc., Cary, NC). A base-10 log-transformation was used to normalize teat sample data. All variables were analyzed as a $3 \times 3$ Latin square design using PROC MIXED of SAS. For all variables, treatment, period, and their interaction were treated as fixed effects, group was treated as random effect, and week as repeated measure. Scheffé pairwise multiple comparisons were performed on treatment means.

\section{RESULTS}

\section{Experiment 1}

Friedman's rank tests revealed differences between bedding types for all variables, except standing bout mean duration (Table 1). When post hoc comparisons were made between the 3 bedding types, duration of time spent lying down was 9.4 times longer and lying bout frequency was 9.1 times greater on SG compared with SGL, but these variables did not differ between SG and WS or between SGL and WS. A 3.3-timeslonger standing duration and a 3.9-times-greater frequency of standing bouts were found on the SG bedding compared with SGL, and standing time was 3.3 times longer on SG compared with WS. No differences in standing behavior were found between SGL and WS (Table 1).

\section{Experiment 2}

The total lying duration, the frequency of lying bouts, and mean lying bout duration did not differ between treatments or time (Table 2).

Bedding DM was lower for SGL than for SG, but did not differ from WS, and was lower on d 13 compared with d 27, whereas DM on d 20 was intermediate (Table 3). Leg cleanliness score did not differ between treatments but increased over time. Flank and udder cleanliness scores were not affected by treatment or time (Table 3).

The count of coliforms on teat ends of cows was higher on SGL than on WS but did not differ from that on SG (Figure 1). No differences between bedding treatments were found for Streptococcus spp. Of all the samples analyzed, only 2 were positive for Klebsiella spp., with a count of $10 \mathrm{cfu} / \mathrm{g}$; thus, statistical analysis could not be performed on this outcome.

\section{DISCUSSION}

The goal of this study was to evaluate the quality, in terms of comfort and hygiene, of 2 types of alternative deep beddings. Our results indicate that SG may in fact be a suitable bedding alternative for dairy cows. 
WOLFE ET AL.

Table 2. Effects of bedding treatments on lying daily duration, bout frequency, and bout duration in experiment 2

\begin{tabular}{|c|c|c|c|c|c|c|c|c|c|c|}
\hline Item & \multicolumn{3}{|c|}{ Bedding treatment ${ }^{1}$} & $\mathrm{SEM}^{2}$ & $P$-value & \multicolumn{3}{|c|}{ Time $^{3}$} & $\mathrm{SEM}^{2}$ & $P$-value \\
\hline \multicolumn{11}{|l|}{$\overline{\text { Lying }}$} \\
\hline Bout frequency (bouts/d) & 8.2 & 7.8 & 8.2 & 0.93 & 0.739 & 8.1 & 8.0 & 8.0 & 0.87 & 0.759 \\
\hline Bout duration (h/bout) & 1.2 & 1.3 & 1.3 & 0.06 & 0.118 & 1.3 & 1.3 & 1.2 & 0.06 & 0.666 \\
\hline
\end{tabular}

${ }^{1} \mathrm{WS}=$ straw; $\mathrm{SG}=$ switchgrass; SGL = switchgrass, water, lime mixture.

${ }^{2}$ Pooled SEM.

${ }^{3} \mathrm{Wk} 1$ = average from d 7 to 13 ; Wk 2 = average from d 14 to 20 ; Wk $3=$ average from $\mathrm{d} 21$ to 27 .

During the preference test, cows lay down and stood up most often and spent the most time standing in the SG stall. Lying duration did not differ between SG and WS but was greater on SG than on SGL. Both lying and standing duration during free-choice tests have been used as indicators of cow preference for a lying surface (Tucker and Weary, 2004). Our results suggest a preference for SG over SGL for both lying and standing. No preference was found between WS and SGL, and the preference for SG over WS was seen only for total time spent standing in the stall. A preference for SG over the WS treatment was expected, given the preference previously observed by Tucker et al. (2003) for deepbedded sawdust and deep-bedded sand stalls over stalls with mattresses covered with 2 to $3 \mathrm{~cm}$ of sawdust. Tucker et al. (2009) found that surface compressibility improved with the quantity of bedding in the stall and reported a relationship between compressibility and lying duration. Compressibility was not measured in the present experiment, but this factor may have influenced cow preferences for lying surfaces, even when comparing the 2 switchgrass deep-bedded surfaces. The base of the SGL treatment contained higher proportions of water and lime than the top mixture and had

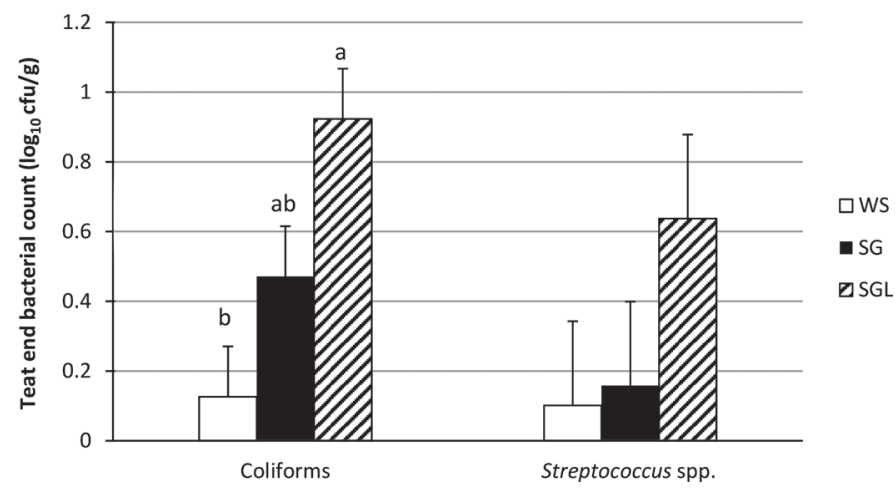

Figure 1. Effect of bedding treatments on teat end counts of coliforms. WS $=$ straw, $\mathrm{SG}=$ switchgrass, $\mathrm{SGL}=$ switchgrass, water, lime mixture. Least squares means $\pm \mathrm{SE}$ with different letters $(\mathrm{a}, \mathrm{b})$ differ $(P<0.05)$. been compacted to form a relatively firm surface on which the top mixture was applied. This lying surface may have been structurally closer to the straw on rubber mat lying surface (WS) than to the deep-bedded switchgrass (SG) in terms of compressibility. Another factor that may have affected preferences is the DM percentage of the bedding, which was highest for SG and lowest for SGL. Cows have been shown to spend more time lying on dry bedding than on wetter bedding (Fregonesi et al., 2007; Reich et al., 2010). It should be noted, however, that differences in DM content of experimental beddings were less pronounced in the present experiment (average range of 63.5 to $68.6 \%$ ) than in these previous experiments (average range of 25.6 to $89.8 \%$ ).

During experiment 2, in which cows did not have the option to choose their lying surface, no differences in lying behavior were observed between bedding treatments, despite a preference shown for the SG treatment in experiment 1. Similarly, Manninen et al. (2002) reported a preference for straw bedding over rubber mat during a preference test, but no difference in total lying time per day when only 1 of these 2 options was available at a time. Sand, on the other hand, was the least preferred during choice tests and resulted in a reduction in total lying time when presented as the only option (Manninen et al., 2002). These results suggest that even though SGL was the least preferred by cows in experiment 1 , cows did not seem to avoid it or find it uncomfortable when it was offered as a single option.

Total lying duration $(9.7 \mathrm{~h} / \mathrm{d})$, bout frequency $(8.1$ bouts/d), and bout duration (1.3 h/bout) observed in the present experiment were within the ranges of 9.5 to $12.9 \mathrm{~h} / \mathrm{d}, 7$ to 10 bouts/d, and 65 to $112 \mathrm{~min} /$ bout reported by Ito et al. (2009) across 43 freestall herd averages. Total lying durations, however, were on average at the lower end of the range $(9.5 \mathrm{~h} / \mathrm{d})$ reported by Ito et al. (2009). Previous research has shown that cows, over a day, lay down longer and more frequently on softer surfaces (Haley et al., 2001; Tucker and Weary, 2004). The relatively short lying durations recorded in 
Table 3. Effects of bedding treatments and time since the beginning of the treatment period on bedding DM and cow cleanliness scores

\begin{tabular}{|c|c|c|c|c|c|c|c|c|c|c|}
\hline Item & \multicolumn{3}{|c|}{ Bedding treatment ${ }^{1}$} & $\mathrm{SEM}^{2}$ & $P$-value & \multicolumn{3}{|c|}{ Time $^{2}$} & $\mathrm{SEM}^{3}$ & $P$-value \\
\hline $\begin{array}{l}\text { Bedding DM (\%) } \\
\text { Cow cleanliness score }{ }^{4}\end{array}$ & $68.6^{\mathrm{ab}}$ & $74.1^{\mathrm{a}}$ & $63.5^{\mathrm{b}}$ & 1.57 & 0.040 & $66.0^{\mathrm{b}}$ & $69.2^{\mathrm{ab}}$ & $70.9^{\mathrm{a}}$ & 1.16 & 0.043 \\
\hline Leg & 0.35 & 0.15 & 0.18 & 0.080 & 0.273 & $0.14^{\mathrm{a}}$ & $0.19^{\mathrm{ab}}$ & $0.35^{\mathrm{b}}$ & 0.060 & 0.047 \\
\hline Flank & 0.08 & 0.04 & 0.03 & 0.024 & 0.449 & 0.05 & 0.04 & 0.06 & 0.036 & 0.931 \\
\hline Udder & 0.05 & 0.16 & 0.04 & 0.093 & 0.464 & 0.14 & 0.00 & 0.11 & 0.098 & 0.492 \\
\hline
\end{tabular}

${ }^{\mathrm{a}, \mathrm{b}}$ Least squares means with different superscripts differ $(P<0.05)$.

${ }^{1} \mathrm{WS}=$ straw; $\mathrm{SG}=$ switchgrass; SGL = switchgrass, water, lime mixture.

${ }^{2}$ Day since the beginning of the treatment period.

${ }^{3}$ Pooled SEM.

${ }^{4}$ Cow cleanliness scores: scale of 0 to $3 ; 0=$ lightly contaminated and $3=$ very heavily contaminated with manure (Vasseur et al., 2015).

our study may be explained by the extended milking period during which cows did not have access to the stalls (only to a holding pen followed by feeding area), limited lunge space (compared with recommended stall dimensions; NFACC-DFC, 2009), and cows having outdoor access (up to $0.5 \mathrm{~h}$ per day). In addition, it was noted that regardless of treatment, cows tended to push their bedding out of their stall and in the alley over time, possibly because the stalls were not equipped with a bedding guard. This might have made their stall less comfortable during the time interval between morning and evening additions of fresh bedding. Tucker et al. (2009) found that cows bedded with $1 \mathrm{~kg}$ of straw/ stall spent less time lying $(11.2 \mathrm{~h})$ than cows bedded with $7 \mathrm{~kg} /$ stall $(12.4 \mathrm{~h})$, but lying times were similar between 3,5 , and $7 \mathrm{~kg} /$ stall.

Positive associations have been found between bacterial counts in bedding material and those on teat ends (Zdanowicz et al., 2004; Proietto et al., 2013). In our study, bacterial counts on teat end of cows were lower overall than those reported by Zdanowicz et al. (2004) for cows on sand or sawdust a day after addition of fresh bedding to the stall. In addition, our average coliform and Klebsiella spp. counts did not reach the maximum average values reported by Proietto et al. (2013) after 7 to $14 \mathrm{~d}$ of treatment. This suggests that the types of bedding and management used in our experiment did not promote high growth of environmental bacteria.

Hogan and Smith (1997) stated that lime added to bedding elevates the $\mathrm{pH}$ and reduces moisture content, which may inhibit bacterial growth. Fairchild et al. (1982) reported that using lime as bedding in freestalls reduced teat swab total coliform and Klebsiella spp. counts compared with sawdust, but adding $18 \mathrm{~kg}$ of lime to the back one-third of sawdust-bedded stalls only reduced Klebsiella spp. count on teat ends. In the present experiment, however, the addition of lime to switchgrass did not have the expected benefit on teat end bacterial contamination, possibly because values were low overall across treatments. In fact, the count of teat end coliforms was found to be higher on SGL than on the other 2 bedding treatments.

The higher bacterial contamination for cows on SGL may also be related to the higher moisture content of this bedding type promoting bacterial growth (Zdanowicz et al., 2004; Proietto et al., 2013), especially during the first week when it was freshly mixed with water. van Weyenberg et al. (2015) compared straw with Miscanthus, another alternative bedding source, in combination with lime, and also reported an increase in DM over time. However, the DM levels reached in their study were higher (over 90\%) than in our study, probably because it was conducted under warmer conditions (fall rather than winter). Miscanthus did not differ from straw in terms of comfort, bedding bacterial growth, cow cleanliness, or skin lesions (van Weyenberg et al., 2015).

All 3 bedding types resulted in low cow cleanliness scores, which did not differ between treatments. This lack of difference in cow cleanliness is in line with the results obtained by van Gastelen et al. (2011) when comparing cows on mattresses with bedding and cows on deep-bedded stalls.

\section{CONCLUSIONS}

Of the 2 deep-bedding alternatives tested in the present experiment, deep-bedded switchgrass appeared to be the most promising alternative to the control (straw on rubber mat). Cows showed a preference for this lying surface when given the choice, and although both deepbedded options were equivalent in terms of lying behavior and cow cleanliness, the higher moisture content and teat end coliform counts on the switchgrass-lime surface make it a less favorable option. A longer-term study is required to confirm this finding. 


\section{ACKNOWLEDGMENTS}

We thank the barn staff at the University of Guelph for their help with feed preparation and care of the animals. Special thanks to the students and research assistants involved in animal care and data collection: Elise Shepley, Lisa Wormsbecher, Nancy Franco-Gendron, Santiago Palacio (University of Guelph, Guelph, ON, Canada), Anne Bastin, Emmanuel Laplante, Julie Beaulieu, Stéphanie Duhamel, Émilie Desjardins (Université de Sherbrooke, Sherbrooke, QC, Canada), and Tommy Perreault (École secondaire catholique de Hawkesbury, Hawkesbury, ON, Canada). This research was funded through Organic Science Cluster II, a project supported by the AgriInnovation Program of Agriculture and Agri-Food Canada's Growing Forward 2 (GF2) Policy Framework and Dairy Farmers of Canada (Ottawa, ON) as the industry partner for this work.

\section{REFERENCES}

AOAC International. 2006. Official Methods of Analyses. 18th ed. AOAC International, Gaithersburg, MD.

Bagley, S. T., and R. J. Seidler. 1978. Primary Klebsiella identification with MacConkey-inositol-carbenicillin agar. Appl. Environ. Microbiol. 36:536-538.

Barrientos, A. K., N. Chapinal, D. M. Weary, E. Galo, and M. A. G. von Keyserlingk. 2013. Herd-level risk factors for hock injuries in freestall-housed dairy cows in the northeastern United States and Canada. J. Dairy Sci. 96:3758-3765.

CCAC (Canadian Council on Animal Care). 2009. Guideline on: the Care and Use of Farm Animals in Research, Teaching and Testing. Canadian Council on Animal Care in Science, Ottawa, ON, Canada.

Fairchild, T. P., B. J. McArthur, J. H. Moore, and W. E. Hylton. 1982. Coliform counts in various bedding materials. J. Dairy Sci. 65:1029-1035.

Fregonesi, J. A., D. M. Veira, M. A. G. von Keyserlingk, and D. M. Weary. 2007. Effects of bedding quality on lying behavior of dairy cows. J. Dairy Sci. 90:5468-5472.

Frigon, J. C., C. Roy, and S. R. Guiot. 2012. Anaerobic co-digestion of dairy manure with mulched switchgrass for improvement of the methane yield. Bioprocess Biosyst. Eng. 35:341-349.

Fulwider, W. K., T. Grandin, D. J. Garrick, T. E. Engle, W. D. Lamm, N. L. Dalsted, and B. E. Rollin. 2007. Influence of free-stall base on tarsal joint lesions and hygiene in dairy cows. J. Dairy Sci. 90:3559-3566.

Haley, D. B., A. M. de Passillé, and J. Rushen. 2001. Assessing cow comfort: effects of two floor types and two tie stall designs on the behaviour of lactating dairy cows. Appl. Anim. Behav. Sci. 71:105-117.

Hogan, J. S., V. L. Bogacz, L. M. Thompson, S. Romig, P. S. Schoenberger, W. P. Weiss, and K. L. Smith. 1999. Bacterial counts as- sociated with sawdust and recycled manure bedding treated with commercial conditioners. J. Dairy Sci. 82:1690-1695.

Hogan, J. S., and K. L. Smith. 1997. Bacteria counts in sawdust bedding. J. Dairy Sci. 80:1600-1605.

Ito, K., D. M. Weary, and M. A. G. von Keyserlingk. 2009. Lying behavior: assessing within- and between-herd variation in free-stallhoused dairy cows. J. Dairy Sci. 92:4412-4420.

Kristula, M. A., Z. Dou, J. D. Toth, B. I. Smith, N. Harvey, and M. Sabo. 2008. Evaluation of free-stall mattress bedding treatments to reduce mastitis bacterial growth. J. Dairy Sci. 91:1885-1892.

Ledgerwood, D. N., C. Winckler, and C. B. Tucker. 2010. Evaluation of data loggers, sampling intervals, and editing techniques for measuring the lying behavior of dairy cattle. J. Dairy Sci. 93:5129-5139

Manninen, E., A. M. de Passille, J. Rushen, M. Norring, and H. Saloniemi. 2002. Preferences for dairy cows kept in unheated buildings for different kind of cubicle flooring. Appl. Anim. Behav. Sci. $75: 281-292$

NFACC-DFC (National Farm Animal Care Council and Dairy Farmers of Canada). 2009. Dairy cattle: Code of practice for the care and handling of dairy cattle. Accessed May 30, 2016. https://www .nfacc.ca/pdfs/codes/dairy_code_of_practice.pdf.

Proietto, R. L., L. S. Hinckley, L. K. Fox, and S. M. Andrew. 2013. Evaluation of a clay-based acidic bedding conditioner for dairy cattle bedding. J. Dairy Sci. 96:1044-1053.

Reich, L. J., D. M. Weary, D. M. Veira, and M. A. von Keyserlingk. 2010. Effects of sawdust bedding dry matter on lying behavior of dairy cows: A dose-dependent response. J. Dairy Sci. 93:1561-1565.

Sanderson, M. A., P. R. Adler, A. A. Boateng, M. D. Casler, and G. Sarath. 2006. Switchgrass as a biofuels feedstock in the USA. Can. J. Plant Sci. 86:1315-1325.

Tucker, C. B., and D. M. Weary. 2004. Bedding on geotextile mattresses: How much is needed to improve cow comfort? J. Dairy Sci. 87:2889-2895.

Tucker, C. B., D. M. Weary, and D. Fraser. 2003. Effects of three types of freestall surfaces on preferences and stall usage by dairy cows. J. Dairy Sci. 86:521-529.

Tucker, C. B., D. M. Weary, M. A. G. von Keyserlingk, and K. A. Beauchemin. 2009. Cow comfort in tie-stalls: Increased depth of shavings or straw bedding increases lying time. J. Dairy Sci. 92:2684-2690.

van Gastelen, S., B. Westerlaan, D. J. Houwers, and F. J. C. M. van Eerdenburg. 2011. A study on cow comfort and risk for lameness and mastitis in relation to different types of bedding materials. J. Dairy Sci. 94:4878-4888.

van Weyenberg, S., T. Ulens, K. De Reu, I. Zwertvaegher, P. Demeyer, and L. Pluym. 2015. Feasibility of Miscanthus as alternative bedding for dairy cows. Vet. Med. Czech. 3:121-132.

Vasseur, E., J. Gibbons, J. Rushen, D. Pellerin, E. Pajor, D. Lefebvre, and A. M. de Passillé. 2015. An assessment tool to help producers improve cow comfort on their farms. J. Dairy Sci. 98:698-708.

Weary, D. M., and I. Taszkun. 2000. Hock lesions and free-stall design. J. Dairy Sci. 83:697-702.

Zdanowicz, M., J. A. Shelford, C. B. Tucker, D. M. Weary, and M. A. G. von Keyserlingk. 2004. Bacterial populations on teat ends of dairy cows housed in free stalls and bedded with either sand or sawdust. J. Dairy Sci. 87:1694-1701. 